\title{
早期胃癌 1000 例の検討
}

\section{一肉眼分類を中心に一}

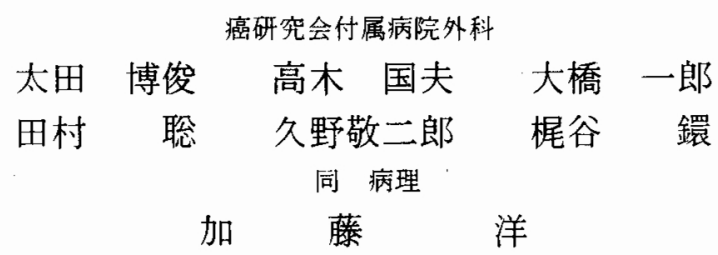

\section{STUDIES OF THE 1000 CASES OF EARLY GASTRIC CANCER -WITH SPECIAL REFERENCE TO MACROSCOPIC CLASSICATION- \\ Hirotoshi OHTA, Kunio TAKAGI, Ichiro OHASHI, Satoru TAMURA, Keijiro KUNO, Tamaki KAJITANI* and Yo KATO**}

Department of Surgery*, Pathology**, Cancer Institute Hospital

当外科において手術された1978年10月までの1,000例の単発早期胃癌に対して肉眼分類を中心に時代的 変貌を加味しつつ, その臨床像を検討した。最近は手術胃癌の 3 例に 1 例は早期癌で, 樎凹型早期癌が多 く, 占居部位では隆起型は胃下部，陥凹型は胃中部に多い。年龄分布はピークが隆起型は60歳代の山型, 宿凹型は50歳代の丘型を示した. 症例数で隆起型と陷凹型は 1 対 4 の比率で, 深達度 $\mathrm{m}$ と $\mathrm{sm}$ ではほ洼 同率であった。早期胃癌のリンバ節転移率は $12.7 \%, \mathrm{~m}$ 癌は $3.4 \%, \mathrm{sm}$ 癌は $21.7 \%$. 隆起型では $20.9 \%$ その内 $\mathrm{m}$ 癌は $1 \%, \mathrm{sm}$ 癌は $33.3 \%$, 陷凹型では $10 \%$ その内 $\mathrm{m}$ 癌は $3.9 \%, \mathrm{sm}$ 癌は16.7\%であった. 治癒切除例の 5 生率は $93.8 \%$ 非治虑切除例で $56.5 \%$ であった。

索引用語 : 早期冒癌肉眼分類, 早期胃癌リンパ節転移, 早期胃癌組織型, 早期胃癌予後

\section{I はじめに}

わが国での悪性新生物による年間死亡者数 ${ }^{1)}$ は1978年 には150,336人にも拉よび，そのうち49,564人（33\%） が胃の 悪性腫瘍 (主に胃癌) で死亡している. 1949年 （昭和24年）以前の胃癌を含めた悪性新生物の年間死亡 順位は 5 位以内には入らず，1950年（昭和 25 年）には 5 位 $(64,428$ 人中，胃の悪性腫瘍 31,211 人， $48.4 \%)$ にな り，1953年（昭和28年）には, 脳血管疾患についで死因 第 2 位 $(150,336$ 人中, 胃の悪性腫瘍49,564人，33\%） を占めるに至り，その後今日までその順位を保ち，1981 年 (昭和56年) には脳血管疾患をしのいで死因第 1 位に ならんとしている.すでに昭和53年度の人口動態による 年跉別死因でみても，働さざかりの30代から60代の死因 のトップは悪性新生物となっている.
このように悪性腫痬の中でも最も多い胃癌での死因が 多いのは, いぜんとして進行した状態で発見され，手術 されているからであり，その予後は必ずしす良好とは言 えない. 外科的治療で予後を $5 \%$ 堌加させることは非常 な努力がいるのである. 早期癌の状態で発見し早期に治 療を行总ば，その予後は，きわめて良好であることは誰 もが認める所である.

1961年に初めて早期胃癌の全国集計がなされた時 ${ }^{2)} に$ は385例と少なく，あとの大半は進行癌であったことを 考えると, 最近は早期癌も多くの施設で数多く発見され るようになり，その予後が良くなりつつあることが期待 できるようになり早期に発見することにより癌による死 亡を減少させることが必要であろう，癌研病院外科で手 術された単発早期胃癌 1,000 例を肉眼分類を中心に，時 
代的変貌を加味しつつ, その臨床像を検討し, 肉眼型に おける特徵と予後を検討する.

\section{II 早期胃癌の年次別頻度（表 1)}

われわれが1946年（昭和21年）から開腹手術した胃癌 症例の中で, 早期胃癌の占める割合は年々増加の一途を たどり，1950年代には1.0〜 5.6\%であったものが，60年 代前半には14.2\%に達し, 著しい增加を示し，60年代後 半には $24 \%$ とさらに早期癌の占める頻度は高くなり，70 年代後半には $34.7 \%$ 一一段と增加し，3例に 1 例は早期 癌の状態で開腹手術を受けている. 近い将来には2 例に 1 例は早期癌で発見される事が期待されよう.

表 1 手術胃癌にお汁る早期胃癌の頻度（1946～ 1978)

\begin{tabular}{|c|c|c|c|}
\hline 年 & 手術胃癌 & 早期癌 & 早期部の顒度 \\
\hline $1946-1950$ & 381 & 4 & $1.0 \%$ \\
\hline $1951-1955$ & 932 & 23 & 2.586 \\
\hline $1956-1960$ & 1313 & 73 & $5.6 \%$ \\
\hline $1961 \sim 1965$ & 1181 & 168 & 14.286 \\
\hline $1966 \sim 1970$ & 1181 & 284 & $24.0 \%$ \\
\hline $1971-1975$ & 1225 & 399 & $32.6 \%$ \\
\hline $1976 \sim 1978$ & 753 & 261 & $34.7 \%$ \\
\hline 計 & 6966 & 1212 & 17.496 \\
\hline
\end{tabular}

i ) 早期胃癌肉眼分類の年次別変遷（表 2)

1950年に早期胃癌を経験して以来，年を経るごとにそ の数は増え1976年 7 月には1,000例（含, 多発癌）を越 之, その後早期胃癌症例は年々増加し単発早期癌症例の みでは1978年10月で1,000例を越えた。
単発早期胃癌 1,000 例を年代別に区分してみると，そ の頻度は50年代は7.8\%，60年代は $34.6 \% ， 70$ 年代は $57.6 \%$ と增兄最近 1 年間の単発早期胃癌症例は 80 例近く 手術されている. 肉眼分類で最も多いのは I c 型で 44.4 \%を占め，ついで II c+ III型滴が $24.7 \%$ り，両者を合 わせると，全早期癌の 7 割近くを占めている.つぎに多 いのが II a 型であるが，前二者に比べその比率には格段 の差があり $9.4 \%, \quad I I a+I \mathrm{c}$ 型が $9 \%$ ， I 型 $7 \% ， \mathbb{I I I}$ $3.9 \%$ ， I b 型1.6\%の順であって， I , II a， II $\mathrm{a}+\mathbf{I I} \mathrm{c}$ の隆起をしめす早期癌は, 全早期癌の $25.4 \%$ 占めてい る.

年代別に肉眼分類の頻度をみると，50年代では II c+ III型が $35.9 \%$ と最も多く，ついでII a， III，II c，II a+ II c，Iが10\%を少しこえる程度であり，IIb が2.6\%で 最も少なかった，最近になるにつれて，IIc+亚型が $35.9 \%$ から $14.4 \%$ に隇少し， II a 型が15.4\%から $8.7 \%$ と減少，II型が $12.8 \%$ から $1.9 \%$ と減少している. それ とは逆に II c 型が $11.5 \%$ から $59.7 \%$ と急増し，70年代の 症例数の半数以上を占めている点が特徵であり ${ }^{3)}, \mathrm{I}$, II a， I a + I c の隆起型早期癌でみた場合，その占め る割合は $37.2 \%$ から $26.3 \%$ に，70年代には $24 \%$ へ之次第 に減少している.このような肉眼分類の占める割合の変 化は，的確な診断能力および技術の向上で，微小な宿山 型早期胃癌が診断可能になったからであろうと推定され $3^{4 / 5)}$.

ii) 肉眼分類別年㱓分布 (表 3, 図 1 )

I , II a，II a + I c の隆起型早期癌では 60 代が最も多 く38.3〜47.1\%を占め, ついで50代の 25.7 27.8\%で60 代より10\%以上の差があり，先の次が70代と40代で10

表 2 早期胃癌肉眼分類の年次的变遷 (単発癌)

\begin{tabular}{c|c|c|c|c}
\hline & $\begin{array}{c}1950 \text { 年代 } \\
(1950 \sim 1959)\end{array}$ & $\begin{array}{c}1960 \text { 年代 } \\
(1960 \sim 1969)\end{array}$ & $\begin{array}{c}1970 \text { 年代 } \\
(1970 \sim 1978 . X)\end{array}$ & 計 \\
\hline I & $8(10.3)$ & $29(8.4)$ & $33(6.4)$ & $70(7.0)$ \\
\hline II a & $12(15.4)$ & $32(9.2)$ & $50(8.7)$ & $94(9.4)$ \\
\hline II a + II c & $9(11.5)$ & $30(8.7)$ & $51(8.9)$ & $90(9.0)$ \\
\hline II b & $2(2.6)$ & $10(2.9)$ & $4(0.7)$ & $16(1.6)$ \\
\hline II c & $9(11.5)$ & $91(26.3)$ & $344(59.7)$ & $444(44.4)$ \\
\hline II c + III & $28(35.9)$ & $136(39.3)$ & $83(14.4)$ & $247(24.7)$ \\
\hline III & $10(12.8)$ & $18(5.2)$ & $11(1.9)$ & $39(3.9)$ \\
\hline 計 & $78(7.8)$ & $346(34.6)$ & $576(57.6)$ & $1000(100)$ \\
\hline & & & & $(j)$
\end{tabular}


表 3 肉眼癌別年令分布

\begin{tabular}{|c|c|c|c|c|c|c|c|c|c|}
\hline & $\sim 29$ & $30 \sim$ & $40 \sim$ & $50 \sim$ & $60 \sim$ & $70 \sim$ & $\hat{\delta}$ & 우 & 計 \\
\hline I & & 3 & $\begin{array}{c}7 \\
(10.0)\end{array}$ & $\begin{array}{c}18 \\
(25.7)\end{array}$ & $\begin{array}{c}33 \\
(47.1) \\
\end{array}$ & $\begin{array}{c}9 \\
(12.8)\end{array}$ & 45 & 25 & 70 \\
\hline II a & 1 & 3 & $\begin{array}{c}12 \\
(12.8)\end{array}$ & $\begin{array}{c}25 \\
(26.6)\end{array}$ & $\begin{array}{c}36 \\
(38.3) \\
\end{array}$ & $\begin{array}{c}17 \\
(18.1)\end{array}$ & 65 & 29 & 94 \\
\hline II $a+$ II $c$ & & 2 & $\begin{array}{c}16 \\
(17.8)\end{array}$ & $\begin{array}{c}25 \\
(27.8)\end{array}$ & $\begin{array}{c}35 \\
(38.9) \\
\end{array}$ & $\begin{array}{c}12 \\
(13.3)\end{array}$ & 62 & 28 & 90 \\
\hline II $\mathrm{b}$ & & 1 & $\left(\begin{array}{c}4 \\
(25.0)\end{array}\right.$ & $(18.8)$ & $(31.3)$ & $\begin{array}{c}3 \\
(18.8)\end{array}$ & 15 & 1 & 16 \\
\hline II $\mathrm{c}$ & 8 & 50 & $\begin{array}{c}123 \\
(27.7)\end{array}$ & \begin{tabular}{|c|}
142 \\
$(32.0)$ \\
\end{tabular} & $\begin{array}{c}99 \\
(22.3)\end{array}$ & 22 & 260 & 184 & 444 \\
\hline II c + III & 4 & 28 & \begin{tabular}{|c|}
88 \\
$(35.6)$ \\
\end{tabular} & $\begin{array}{c}73 \\
(29.6)\end{array}$ & $\begin{array}{c}46 \\
(18.6)\end{array}$ & 8 & 140 & 107 & 247 \\
\hline 田 & 1 & 2 & $\begin{array}{c}7 \\
(17.9)\end{array}$ & $\begin{array}{c}14 \\
(35.9 \\
\end{array}$ & $\begin{array}{c}11 \\
(28.2)\end{array}$ & 4 & 30 & 9 & 39 \\
\hline 計 & 14 & 89 & 257 & 300 & 265 & 75 & 617 & 383 & 1000 \\
\hline
\end{tabular}

図 1 肉眼型別年令分布 (年次別)

隆起型早期癌

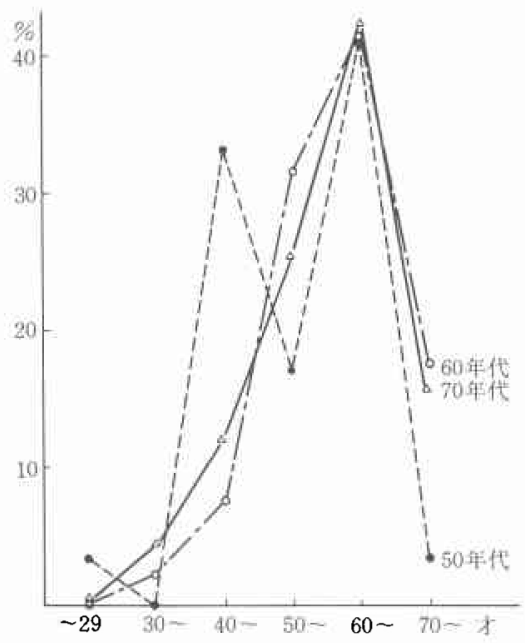

18\%であった.これに対して, II c，II c+II， II の陥 凹型早期癌では，50代（II c十 IIIでは40代）が最も多く 32〜35\%を占め，40代から60代の間に大きな格差はな い. 総じて隆起型，陥凹型に大別してみると図1の如く で, 隆起型では60代をピークに山型の分布をし，陥凹型 は50代をピークに丘型の分布を示し, 両者の間に10年の ずれがあることは注目すべき事である.

な扐，性差については1.6対 1 の割合で男に多く，隆 起型早期癌では2.1対 1 で 2 倍の割合で男性に多く, 陥 凹型早期癌では1.5対 1 であった.
陷凹型早期癌

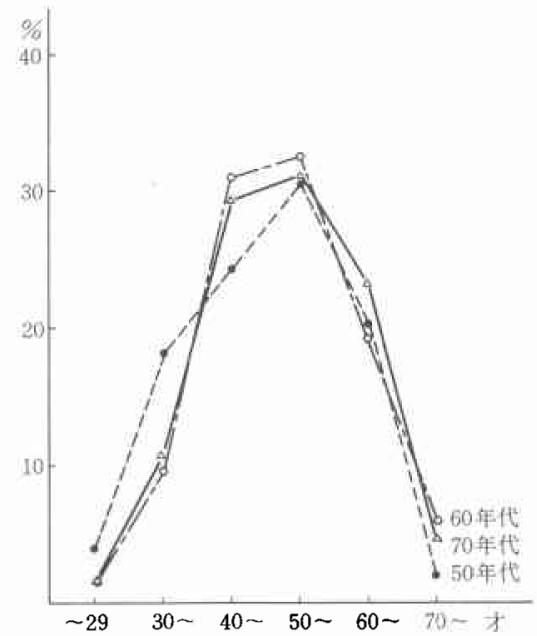

iii）肉眼分類別にみた占居部位（表 4)

早期胃癌の主病巣占居部位は，表 4 の如くであって， 隆起型に打いては，50年代では胃下部に圧倒的に多く， 29例中22例 (75.9\%) を占めたが, 時代とともに60年代 $67 \% ， 70$ 年代 $44.8 \%$ と減少した，逆に胃中部は $20.7 \%$ か ら44\%と増加し，胃下部と胃中部の間に差がなくって来 ている. また，70年代にはそれ以前にはなかった全胃に 広がったものも 3 例認められた. 胃上部では50年代, 60 年代には 3\%台の頻度であったが，70年代になり $9 \%$ と 増古, 胃上部の隆起性病変も診断技術の進歩により発見 
表 4 肉眼分類別占居部位（年次別）

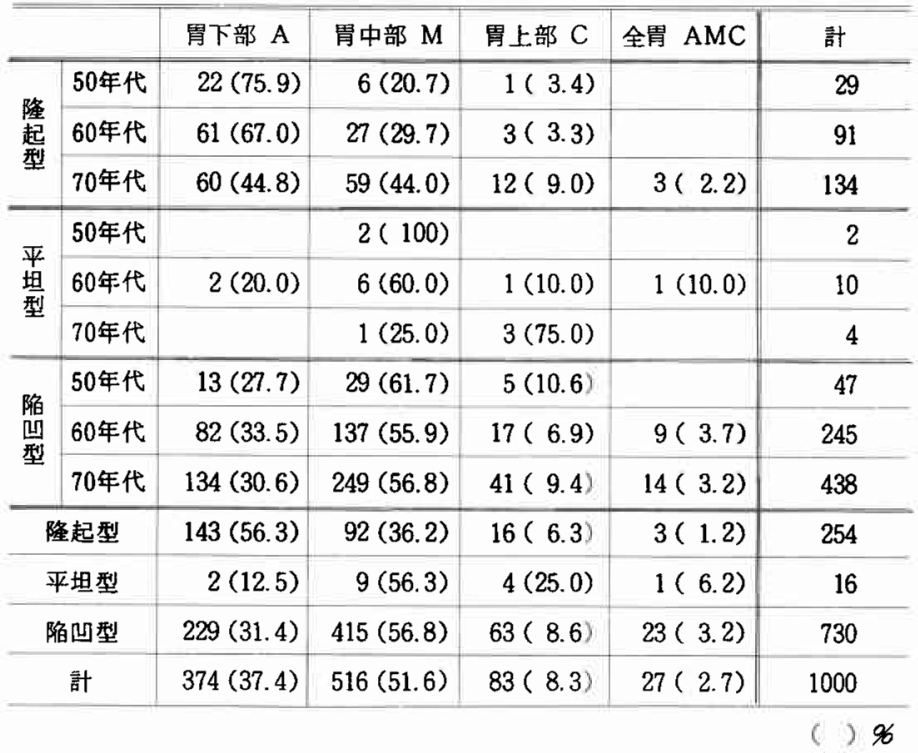

困 2 早期胃癌の年代別最大径別頻度

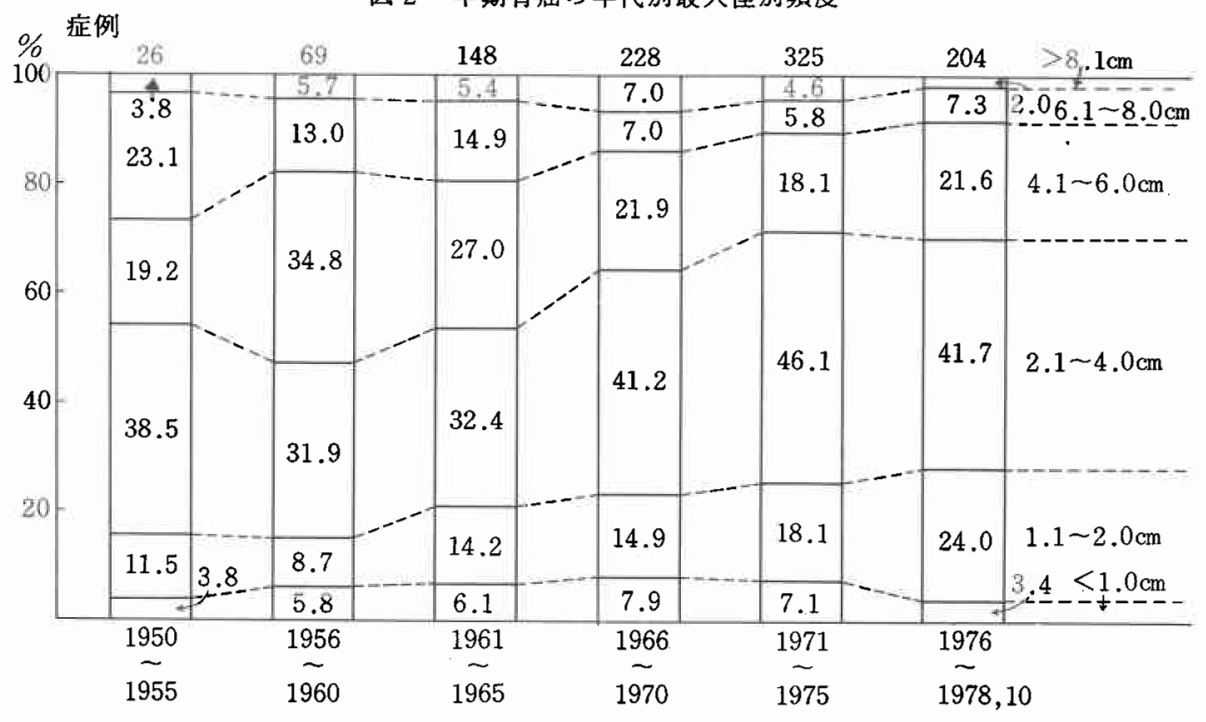

され，わずかながら増加を示している. 陥凹型において は，各年代を通じて，胃下部に30\%前後，胃中部に60\% 前後, 胃上部に $10 \%$ 前後, 全胃 $3 \%$ にみられ, 胃中部に 占居する率が高く, 隆起型にみるよらな時代変貌はみと められなかった。

iv) 癌巣の大きさ（最大径）（図2）

癌巣の最大径別に $1.0 \mathrm{~cm}$ 以下, $1.1 \sim 2.0 \mathrm{~cm}, 2.1 \sim$
$4.0 \mathrm{~cm}, 4.1 \sim 6.0 \mathrm{~cm}, 6.1 \sim 8.0 \mathrm{~cm}, 8.1 \mathrm{~cm}$ 以上之区分 してみると図 2 のごとく，最大径が $1.0 \mathrm{~cm}$ 以下のもの と $8.1 \mathrm{~cm}$ 以上の表層桩大型早期癌では, 年次的に大き な変動はなく, 前者は3.8～7.9\%および後者は2.0 7.0 \%と少なかった. また，2.1〜4.0cm のるのと，4.1〜 $6.0 \mathrm{~cm}$ のるのでは年次的にわずかな変動はあるが前者 は40\%前後であり，後者は20\%前後であった，最大径 
図 3 早期胃癌1000例の術前診断（年次別, 肉眼型別) 一単発癌一（1946～1978. 10）

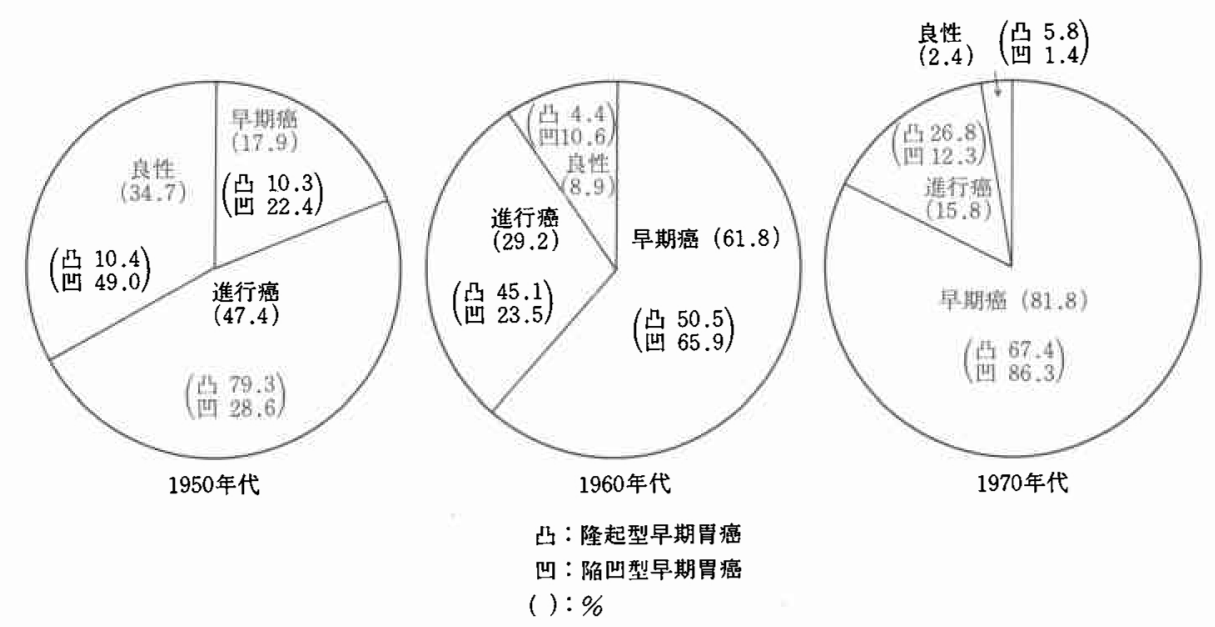

$6.1 \sim 8.0 \mathrm{~cm}$ のものでは 50 年前半に $23.1 \%$ のっもの が60年代には14.9\%となりさらに7.3\%へと減少してい る.こ礼とは反対に $1.1 \sim 2.0 \mathrm{~cm}$ のものでは 50 年代の 10 $\%$ 前後に比べて著しく増加し，最近では $24 \%$ と 2 倍以上 に増加している.すなわち，早期胃癌を最大径で年次別 にみた時, 初期の頃に比べて, 小さな癌の発見率が増加

していると言える.

v) 術前診断状況 (図 3)

1978年迄の 29 年間といら長い藏月の間には診断学およ び診断用機器, 技術の発達もまたらつり変っていった訳 である゙'がそここに集積された早期胃癌1,000例の手術前 の診断が，どのように変化したかをみると，50年代は術 前早期癌診断率は $17.9 \%$ であり, 進行癌（疑進行癌を含 む）としたるのが47.4\%を占め，良性疾患としたものが $34.7 \%$ あり，その多くは潰瘍性病変として開腹手術さ れたものであった. 早期癌肉眼分類ができた 60 年代，そ の後の70年代と らつり変わるごとに早期癌診断率は急激 に向上し，70年代には81.8\%の正診率を得たが，なお進 行癌（疑進行癌を含む）としたものが $15.8 \%$ あり，良性 疾患が $2.4 \%$ に認められた。早期癌を隆起型，陥凹型に 大別して比較してみると, 隆起型の早期癌㟝断率は各年 代とも陥凹型より低く，また進行癌と診断したもので は, 隆起型の方が高かった. 総じて, 「癌」とした診断 率は50年代 $65.3 \% ， 60$ 年代 $91 \% ， 70$ 年代 $97.6 \%$ 年を追 らごとに向上してきている. 50，60年代では隆起型の方 が陥凹型よりも癌診断率は高率であり，良性と診断した 率は陷凹型に高い.70年代では逆に陥凹型の方が癌診断 率は高くなり，良性診断率が隆起型の方に高くなってい
る.このことは，胃生検による診断技術の進歩はあった ものの, かえって, 隆起型には, 生検で境界病変 group III と診断されたものがあって，その為に癌を否定しえず に手術され詳細な組織検査で癌とされたものが多かった ためと考觉られる.

vi) 肉眼分類亡併存病変 (表 5)

胃という臓器は, 多彩な病変を有するものである. 主 病巣の癌を発見しても安心せずに主病巣以外の部位にも 注意をはらい入念に検することが必要で，そのことより 併存病変がしばしば発見されるものである. とくに胃切 除に際し, 残胃に病変のない事をたしかめることが必要 であり, 主病巣の診断とともに他の部位の精査をする態 度や努力が同時多発癌発見への足がかりにるなるのであ る.

早期癌に良性併存病変の合併頻度は $32.1 \%$ で隆起型癌 では $46.1 \%$, 陷山型癌では $26.4 \%$ て隆起型癌に併存病変 の煩度が高かった. 併存病変の中では, ポリープ合併頻 度は隆起型39/254（15.4\%）で，陷凹型の24/730（3.3 \%)に比べて高率で，さらに異型上皮の併存率子II a 型 は17\%，I 型7.1\%であるのに対し，陥凹型では26/730 （3.6\%）と低く, I 型やII a 型ではポリープや ATP の併存率が高かった. II $\mathrm{a}+\mathrm{I} \mathrm{c}$ 型では, 潰瘍病変の併 存率が高かった.このことは主病巣に隆起部の他に陥山 性病変を併っていることが一因ではないかと愚考してい る. II c 型や，II c + II 型では潰瘍病変の併存率が $20 \%$ 以上之高く, 隆起型には隆起性病変, 陷凹型には潰瘍病 変の合併率が高いことを示している7”.

vii）早期胃癌発見経路（表 6, 表 7) 
表 5 早期胃癌と併存病変（病巣数）

\begin{tabular}{|c|c|c|c|c|c|c|c|c|c|}
\hline \multicolumn{2}{|c|}{ 肉眼型 併存病变 } & Ulcer & Polyp & ATP & myoma & その他 & 計 & 症例数 & 合併頻度 \\
\hline \multirow{3}{*}{ 隆起型 } & I & $\left(\begin{array}{c}9 \\
(12.9)\end{array}\right.$ & $\begin{array}{c}15 \\
(21.4)\end{array}$ & $\begin{array}{c}5 \\
(7.1)\end{array}$ & 0 & 3 & $\begin{array}{c}32 \\
(45.7)\end{array}$ & 70 & \multirow{3}{*}{$\begin{array}{c}117 / 254 \\
(46.1)\end{array}$} \\
\hline & II a & $\begin{array}{c}13 \\
(13.8)\end{array}$ & $\begin{array}{c}16 \\
(17.0)\end{array}$ & $\begin{array}{c}16 \\
(17.0)\end{array}$ & 3 & 3 & $\begin{array}{c}51 \\
(54.3)\end{array}$ & 94 & \\
\hline & $\mathrm{II} \mathrm{a}+\mathrm{II} \mathrm{c}$ & $\begin{array}{c}19 \\
(21.1)\end{array}$ & 8 & 2 & 0 & 5 & $\begin{array}{c}34 \\
(38.8)\end{array}$ & 90 & \\
\hline 平坦型 & II $\mathrm{b}$ & 5 & 1 & 3 & 1 & 1 & $\begin{array}{c}11 \\
(68.8)\end{array}$ & 16 & $\begin{array}{l}11 / 16 \\
(68.7)\end{array}$ \\
\hline \multirow{3}{*}{ 宿凹型 } & II $\mathrm{c}$ & $\begin{array}{c}93 \\
(20.9)\end{array}$ & $\begin{array}{l}19 \\
(4.3)\end{array}$ & $\left(\begin{array}{l}17 \\
3.8)\end{array}\right.$ & 1 & 12 & $\begin{array}{c}142 \\
(32.0)\end{array}$ & 444 & \multirow{3}{*}{$\begin{array}{c}193 / 730 \\
(26.4)\end{array}$} \\
\hline & II $c+$ III & $\begin{array}{l}20 \\
(8.1)\end{array}$ & $\begin{array}{c}5 \\
(2.0)\end{array}$ & $\left(\begin{array}{c}9 \\
(3.6)\end{array}\right.$ & 4 & 3 & $\begin{array}{c}41 \\
(16.6)\end{array}$ & 247 & \\
\hline & III & $\begin{array}{c}10 \\
(25.6)\end{array}$ & 0 & 0 & 0 & 0 & $\begin{array}{c}10 \\
(25.6)\end{array}$ & 39 & \\
\hline \multicolumn{2}{|c|}{ 計 } & 169 & 64 & 52 & 9 & 27 & $\begin{array}{c}321 \\
(32.1)\end{array}$ & 1000 & $\begin{array}{c}321 / 1000 \\
(32.1)\end{array}$ \\
\hline
\end{tabular}

表 6 早期胃癌発見場所の分析

\begin{tabular}{|c|c|c|c|c|c|c|}
\hline 肉眼型 & 本院 & 他院 & $\begin{array}{l}\text { 集検 } \\
\text { 検崄 }\end{array}$ & 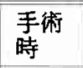 & 病理 & 計 \\
\hline I & 29 & 17 & 19 & 1 & 4 & 70 \\
\hline II a & 48 & 18 & 20 & 2 & 6 & 94 \\
\hline II $\mathrm{a}+$ II $\mathrm{c}$ & 52 & 21 & 14 & 3 & 0 & 90 \\
\hline II $\mathrm{b}$ & 6 & 0 & 2 & 0 & 8 & 16 \\
\hline II $\mathrm{c}$ & 190 & 127 & 105 & 12 & 10 & 444 \\
\hline II $c+$ III & 137 & 62 & 27 & 17 & 4 & 247 \\
\hline III & 19 & 5 & 2 & 5 & 8 & 39 \\
\hline 計 & $\begin{array}{c}481 \\
(48.1)\end{array}$ & $\begin{array}{c}250 \\
(25.0)\end{array}$ & $\begin{array}{c}189 \\
(18.9)\end{array}$ & $\begin{array}{c}40 \\
(4.0)\end{array}$ & $\begin{array}{c}40 \\
(4.0)\end{array}$ & $\begin{array}{l}1000 \\
(100)\end{array}$ \\
\hline
\end{tabular}

\section{一いかなる場所にて発見されたか一}

癌研病院外科で手術された 単発早期胃癌1,000例がい かなる施設において最初に発見され診断されたかを検
討してみると，当院外来で発見された例は481例（48.1 \%)であって，他院での発見例が250例（25\%）であっ た. 集団検診や健康診断，トッッにて発見されたものが 189例と 2 割近くを占め, その殆んどが無症状型8)であっ た. 最近は，他院を経て入院し，手術されている例の中 にも，初回に集団検診や健康診断やドック発見例が增加 してきている. 手術時に発見されたものが40例あり，そ の大半は50年代と60年代前半のものであるが（表 7 ), 良性疾患と診断したものが癌であったり，良性疾患とは 別に癌がみつかったものであった，病理組織検査時に癌 が発見されたものが 40 例で, 肉眼的にも判別出来なかっ た例である ${ }^{9}$. 手術時や病理組織検索中の発見例は50年 代や60年代初めの頃に多く，最近の症例で術前診断で良 性としたものは大部分が生検組織猃断で group III と診断 されたもので，境界病変と診断したものの癌を否定しえ ずに手術されたものが少数例みとめられている．将来は

表 7 検診・手術時・病理発見例の年代別頻度

\begin{tabular}{|c|c|c|c|c|c|c|c|}
\hline 年 代 & $1950 \sim 1955$ & $1956 \sim 1960$ & $1961 \sim 1965$ & $1966 \sim 1970$ & $1971 \sim 1975$ & $1976 \sim 1978$ & 計 \\
\hline 疗例 & 26 & 69 & 148 & 228 & 325 & 204 & 1000 \\
\hline $\begin{array}{l}\text { 集団, Dock } \\
\text { 検診発見例 }\end{array}$ & & $\begin{array}{r}1 / 69 \\
(1.4)\end{array}$ & $\begin{array}{l}3 / 148 \\
(2.0)\end{array}$ & $\begin{array}{l}43 / 228 \\
(18.9)\end{array}$ & $\begin{array}{l}87 / 325 \\
(26.8)\end{array}$ & $\begin{array}{l}55 / 204 \\
(27.0)\end{array}$ & $\begin{array}{c}189 / 1000 \\
(18.9)\end{array}$ \\
\hline $\begin{array}{l}\text { 手術時発見 } \\
\text { 例 }\end{array}$ & & $\begin{array}{l}22 / 69 \\
(31.9)\end{array}$ & $\begin{array}{l}17 / 148 \\
(11.5)\end{array}$ & $\begin{array}{l}1 / 228 \\
(0.4)\end{array}$ & & & $\begin{array}{l}40 / 1000 \\
(4.0)\end{array}$ \\
\hline 病理発見例 & $\begin{array}{c}6 / 26 \\
(23.1)\end{array}$ & $\begin{array}{r}9 / 69 \\
(13.0)\end{array}$ & $\begin{array}{l}7 / 148 \\
(4.7)\end{array}$ & $\begin{array}{l}7 / 228 \\
(3.1)\end{array}$ & $\begin{array}{l}9 / 325 \\
(2.8)\end{array}$ & $\begin{array}{l}2 / 204 \\
(1.0)\end{array}$ & $\begin{array}{l}40 / 1000 \\
(4.0)\end{array}$ \\
\hline
\end{tabular}


表 8-a 早期胃癌のリンパ節転移と深達度

\begin{tabular}{|c|c|c|c|c|c|c|c|c|}
\hline & 深達度 & $\mathrm{n}_{0}(-)$ & $n_{1}(+)$ & $\mathrm{n}_{2}(+)$ & $\mathrm{n}_{3}(+)$ & $\mathrm{n}_{4}(+)$ & & \\
\hline \multirow{2}{*}{ I 型 } & $\mathrm{m}$ & 34 & & & & & 34 & \multirow{2}{*}{70} \\
\hline & $\mathrm{sm}$ & 24 & 8 & 2 & 2 & & 36 & \\
\hline \multirow{2}{*}{ II a 型 } & $\mathrm{m}$ & 48 & 1 & & & & 49 & \multirow{2}{*}{94} \\
\hline & $\mathrm{sm}$ & 31 & 6 & 7 & & 1 & 45 & \\
\hline \multirow{2}{*}{ II $\mathbf{a}+$ II $\mathbf{c}$ 型 } & $\mathrm{m}$ & 15 & & & & & 15 & \multirow{2}{*}{90} \\
\hline & sm & 49 & 19 & 5 & 1 & 1 & 75 & \\
\hline \multirow{2}{*}{ II b 型 } & $\mathrm{m}$ & 12 & 1 & & & & 13 & \multirow{2}{*}{16} \\
\hline & sm & 3 & & & & & 3 & \\
\hline \multirow{2}{*}{ II c 型 } & $\mathrm{m}$ & 236 & 4 & & & & 240 & \multirow{2}{*}{444} \\
\hline & $\mathrm{sm}$ & 175 & 22 & 4 & 1 & 2 & 204 & \\
\hline \multirow{2}{*}{ II c + III 型 } & $\mathrm{m}$ & 114 & 6 & 3 & & & 123 & \multirow{2}{*}{247} \\
\hline & $\mathrm{sm}$ & 97 & 18 & 9 & & & 124 & \\
\hline \multirow{2}{*}{ III型 } & $\underline{m}$ & 18 & 1 & 1 & & & 20 & \multirow{2}{*}{39} \\
\hline & $\mathrm{sm}$ & 17 & 2 & & & & 19 & \\
\hline \multirow[t]{2}{*}{ 詰 } & $\mathrm{m}$ & 477 & 13 & 4 & 0 & 0 & 494 & \multirow{2}{*}{1000} \\
\hline & $\mathrm{sm}$ & 396 & 75 & 27 & 4 & 4 & 506 & \\
\hline
\end{tabular}

表 8-b 早期胃癌のソンパ節転移と深達度

\begin{tabular}{|c|c|c|c|c|c|c|c|c|c|}
\hline 肉眼型 & 深達度 & $\mathrm{n}_{0}(-)$ & $\mathrm{n}_{1}(+)$ & $\mathrm{n}_{2}(+)$ & $n_{3}(+)$ & $\mathrm{n}_{4}(+)$ & 計 & \multicolumn{2}{|c|}{ 軽移率 } \\
\hline \multirow{2}{*}{$\begin{array}{l}\text { 隆起型 } \\
254 \text { 例 }\end{array}$} & $\mathrm{m}$ & 97 & 1 & & & & 98 & $\begin{array}{c}1 / 98 \\
(1.0) \\
\end{array}$ & \multirow{2}{*}{$\begin{array}{l}53 / 254 \\
(20.9)\end{array}$} \\
\hline & $\mathrm{sm}$ & 104 & 33 & 14 & 3 & 2 & 156 & $\begin{array}{l}52 / 156 \\
(33.3)\end{array}$ & \\
\hline \multirow{2}{*}{$\begin{array}{l}\text { 平坦型 } \\
16 \text { 例 }\end{array}$} & $\mathrm{m}$ & 12 & 1 & & & & 13 & $\begin{array}{r}1 / 13 \\
(7.7) \\
\end{array}$ & \multirow{2}{*}{$\begin{array}{c}1 / 16 \\
\left(\begin{array}{c}6.3)\end{array}\right)\end{array}$} \\
\hline & $\mathrm{sm}$ & 3 & & & & & 3 & $\begin{array}{c}0 / 3 \\
(\quad 0) \\
\end{array}$ & \\
\hline \multirow{2}{*}{$\begin{array}{l}\text { 宿凹型 } \\
730 \text { 例 }\end{array}$} & $\mathrm{m}$ & 368 & 11 & 4 & & & 383 & $\begin{array}{l}15 / 383 \\
(3.9)\end{array}$ & \multirow{2}{*}{$\begin{array}{c}73 / 730 \\
(10.0)\end{array}$} \\
\hline & sm & 289 & 42 & 13 & 1 & 2 & 347 & $\begin{array}{l}58 / 347 \\
(16.7) \\
\end{array}$ & \\
\hline \multirow{2}{*}{1000 例 } & sm & 477 & 13 & 4 & & & 494 & $\begin{array}{l}17 / 494 \\
(3.4)\end{array}$ & \multirow{2}{*}{$\begin{array}{c}127 / 1000 \\
(12.7)\end{array}$} \\
\hline & sm & 396 & 75 & 27 & 4 & 4 & 506 & $\begin{array}{c}110 / 506 \\
(21.7)\end{array}$ & \\
\hline
\end{tabular}

集団検診の普及により，集検で発見される割合がますま す高くなると考光られる ${ }^{10)}$.

viii）肉眼分類別りンパ節転移々深達度（表 8-a, b) 1,000 例の早期癌の深達度についてみると， $\mathrm{m}$ 癌は 494例, sm 癌は506例で, その比率は, ほぼ半数づつで あった. I , II a， I a + I c の隆起型早期胃癌254例中 sm 癌が156例 $(61.4 \%)$ と多いのに比へ， II c， II c+
III， II の陥凹型早期癌730例中では， $\mathrm{m}$ 癌の方が383例 (52.5\%) とやや多かった. 早期胃癌のリンパ節転移陽 性率は $12.7 \%$ (127/1000) で，隆起型の転移率は $20.9 \%$ (53/254) で，陥凹型の転移率10\%（73/730）の 2 倍で あった. $\mathrm{m}$ 癌の転移率は3.4\% (17/494) で， $\mathrm{sm}$ 癌では $21.7 \%(110 / 506)$ で， $\mathrm{sm}$ 癌のリンパ節転移率は $\mathrm{m}$ 癌 の 6 倍強であった ${ }^{11)} . \mathrm{m}$ 癌のリンパ節転移陽性例は17例 
あり，隆起型 1\% (1/98), 陥凹型3.9\% (15/383) であ り, 平担型に 1 例認め 17 例中15例が陥凹型であった。従 来, 深達度 $\mathrm{m}$ の隆起型早期癌ではりンパ節転移を認め ない報告が多かったが(2)われわれは胃前庭部のI $\mathrm{a}+\mathrm{I}$ 型, $35 \times 15 \mathrm{~mm}$ の $\mathrm{m}$ 型早期癌が幽門下リンパ節に転移 を認めた1例を経験したことは注目すべきことである.

またI b 型早期癌でリンパ節転移を認めた 1 例をる経 験した. この症例は，噴門下小弯後壁に $50 \times 25 \times 25 \mathrm{~mm}$ の Leiomyoma があり, 噴門側切除後, 病理組織検索の 結果, 良性腫瘍に近接して長径 $5 \mathrm{~mm}$ のI b 型 $\mathrm{m}$ 癌が 判明し，近接小弯りン八節に転移を認めたものである. 組織型は $\mathrm{tub}_{1}$ であった。

深達度 $\mathrm{sm}$ での隆起型早期癌のリンパ節転移率は 33.3 \% (52/156) で， 陥凹型早期癌のリンパ節転移 $16.7 \%$ （58/347）上り高率であった. リンパ節転移の程度で みてみると， $\mathrm{n}_{1} \oplus か ゙$ 隆起型 sm 癌で21.2\% (33/156), 宿凹型 sm 癌で12.1\% (42/347) であり, $\mathrm{n}_{2} \oplus$ Ð゙は隆 起型 $\mathrm{sm}$ 癌で $9.0 \%$ (14/156), 陥凹型 $\mathrm{sm}$ 癌で 3.7\% (13/347) であり， $\mathrm{n}_{3}, \mathrm{n}_{4}$ リンパ節への転移率む隆起型 sm 癌で3.2\% (5/156), 陥凹型 sm 癌で, $0.9 \%(3 / 347)$ と隆起型 $\mathrm{sm}$ 癌汇高い頻度を示した.

ix) 肉眼分類と組織学的進行程度 (表 9)

早期癌の定義が，癌が粘膜内掞よび粘膜下層に止まる わので転移（とくにリンパ節転移）の有無を問わないる のであるから，早期胃癌といわれるものでる，いわゆる 初期の段階にとどまるもののみではない，進行癌と同じ 様に遠隔転移（肝転移 etc）をしているものも 3 例認め られている. stage 分類をみると, stage I が87.3\%と多 く, stage II が8.7\%であった. しかし stage IVに属す る症例が10例 (1\%) 認められた．全例深達度 smであ り stage IVの10例中 7 例が隆起型早期癌で stage IVを規

表 9 肉眼分類別にみた進行程度（組織学的）

\begin{tabular}{c|c|c|c|c|c}
\hline 肉眼分類 & stage I & stage II & stage III & stage IV & 計 \\
\hline I & 58 & 7 & 2 & 3 & 70 \\
\hline II a & 79 & 7 & 7 & 1 & 94 \\
\hline II a + II c & 64 & 18 & 5 & 3 & 90 \\
\hline II b & 15 & 1 & 0 & 0 & 16 \\
\hline II C & 411 & 27 & 3 & 3 & 444 \\
\hline II c + II & 211 & 24 & 12 & 0 & 247 \\
\hline III & 35 & 3 & 1 & 0 & 39 \\
\hline 計 & 873 & 87 & 30 & 10 & 1000 \\
\hline
\end{tabular}

表10 部位別リンパ節転移陽性数

\begin{tabular}{|c|c|c|c|c|}
\hline リンパ節名 & 胃下部 & $\begin{array}{c}\mathrm{M} \\
\text { 胃中部 }\end{array}$ & $\begin{array}{c}\mathrm{C} \\
\text { 胃上部 }\end{array}$ & $\begin{array}{l}\mathrm{AMC} \\
\text { 全 胃 }\end{array}$ \\
\hline 1. 右 噴 門 & 1 & 2 & 1 & \\
\hline 2. 左 噴 門 & & 1 & & \\
\hline 3. 小 & $26(7.0)$ & $33(6.4)$ & $8(9.6)$ & $6(22.2)$ \\
\hline 4. 大 & $21(5.6)$ & $14(2.7)$ & & 1 \\
\hline 5. 門 上 & 4 & 1 & & \\
\hline 6. 門 下 & $40(10.7)$ & 5 & & \\
\hline 7. 左胃動脈幹 & 3 & 6 & 1 & 1 \\
\hline 8. 総肝動眽幹 & 14 & 3 & & 1 \\
\hline 9. 腹腔動周 囲 & 7 & 7 & & 1 \\
\hline 10. 脾 & & & 2 & \\
\hline 11. 脾 動 脈 幹 & & 1 & & \\
\hline 12. 奣 & & & & \\
\hline 13. 膵 後 部 & 3 & & & \\
\hline 14. 腸間瞙根部 & 2 & & & \\
\hline 15. 中 結 成 & 2 & & & \\
\hline 16. 大 動 眽 & 4 & & & \\
\hline 症 例 数 & 374 & 516 & 83 & 27 \\
\hline
\end{tabular}

定する因子は肝転移 3 例, リンパ節転移 3 例, 播種 1 例 であって，その頻度は2.8\%（7/254）であった. 他方, 陥凹型早期癌では stage IVは 3 例で, その規定因子は全 例リン八゚節転移 $\mathrm{n}_{3} \oplus 1$ 例， $\mathrm{n}_{4} \oplus 2$ 例でその頻度は0.4 \%（3/730）であった. 隆起型早期癌の方が陥凹型早期 癌より stage IVKなる頻度は 7 倍と多かった。

x）部位別リンパ節転移陽性例（表10）

早期癌之言えどる $12.7 \%$ にンン゚節転移があり，告の 転移陽性リンパ節の部位は病巣近傍から大動脈周囲リン パ節にまで及ぶことが認められた，早期胃癌の発生部位 別にリンパ節転移状熊をみると, 胃中部より噴門側に病 巣があるM，Cのるのでは，小弯リンパ節転移が多く, 胃下部Aでは幽門下リンパ節への転移率が 他の部位に 比して多くみとめられた. 第 2 次りンパ節転移陽性 $\left(\mathrm{n}_{2}\right.$ 甲) では(7)番(8)番, (9)番 ${ }^{13}$ 比多く認められ，8)番は胃下 部癌でとくに多く，早期癌と言党どもリンパ節廓清の上 から治窟切除とするためには $\mathrm{n}_{2}$ 群までのリンパ節颜清 が必要である ${ }^{14 / 15}$.

xi）肉眼分類別組織型（表11）

早期胃癌を肉眼分類し, 組檥型を中村 ${ }^{16}$ とよる分化 型, 未分化型飞大別してみると, 隆起型早期癌に扰いて 
表11 肉眼型と組樀型の年代別分布

\begin{tabular}{|c|c|c|c|c|c|c|c|c|c|}
\hline \multirow{2}{*}{\multicolumn{2}{|c|}{ 肉眼分類 組織型 }} & \multicolumn{2}{|c|}{ 1950年代 } & \multicolumn{2}{|c|}{ 1960年代 } & \multicolumn{2}{|c|}{ 1970年代 } & \multicolumn{2}{|c|}{ 計 } \\
\hline & & 分化 & 未分化 & 分化 & 未分化 & 未分 & 未分化 & 分化 & 末分化 \\
\hline \multirow{3}{*}{ 隆起型 } & I & $\begin{array}{c}8 \\
(100)\end{array}$ & & $\begin{array}{c}29 \\
(100)\end{array}$ & & $\begin{array}{c}31 \\
(93.9)\end{array}$ & $(6.1)$ & $\begin{array}{c}68 \\
(97.1)\end{array}$ & $\begin{array}{c}2 \\
(2.9)\end{array}$ \\
\hline & II a & $\begin{array}{c}11 \\
(91.7)\end{array}$ & $\left(\begin{array}{c}1 \\
8.3\end{array}\right)$ & $\begin{array}{c}30 \\
(93.8)\end{array}$ & $\left(\begin{array}{c}2 \\
(6.2)\end{array}\right.$ & $\begin{array}{c}43 \\
(86.0)\end{array}$ & $\left(\begin{array}{c}7 \\
(14.0)\end{array}\right.$ & $\begin{array}{c}84 \\
(89.4)\end{array}$ & $\begin{array}{c}10 \\
(10.6)\end{array}$ \\
\hline & $\mathrm{II} \mathrm{a}+\mathrm{II} \mathrm{c}$ & $\begin{array}{c}9 \\
(100)\end{array}$ & & $\begin{array}{c}29 \\
(96.7)\end{array}$ & ( 3.3$)$ & $\begin{array}{c}33 \\
(64.7)\end{array}$ & $\begin{array}{c}18 \\
(35.3)\end{array}$ & $\begin{array}{c}71 \\
(78.9)\end{array}$ & $\begin{array}{c}19 \\
(21.1)\end{array}$ \\
\hline 平坦型 & II $\mathrm{b}$ & & $\begin{array}{c}2 \\
(100)\end{array}$ & $\begin{array}{c}7 \\
(70.0)\end{array}$ & $\left(\begin{array}{c}3 \\
(30.0)\end{array}\right.$ & $\begin{array}{c}4 \\
(100)\end{array}$ & & $\begin{array}{c}11 \\
(68.8)\end{array}$ & $\begin{array}{c}5 \\
(31.2)\end{array}$ \\
\hline \multirow{3}{*}{ 陥凹型 } & II $\mathrm{C}$ & $\begin{array}{c}3 \\
(33.3)\end{array}$ & $\begin{array}{c}6 \\
(66.7)\end{array}$ & $\begin{array}{c}29 \\
(31.9)\end{array}$ & $\begin{array}{c}62 \\
(68.1)\end{array}$ & $\begin{array}{c}126 \\
(36.6)\end{array}$ & $\begin{array}{c}218 \\
(63.4)\end{array}$ & $\begin{array}{c}158 \\
(35.6)\end{array}$ & $\begin{array}{c}286 \\
(64.4)\end{array}$ \\
\hline & II $c+$ III & $\begin{array}{c}14 \\
(50.0)\end{array}$ & $\begin{array}{c}14 \\
(50.0)\end{array}$ & $\begin{array}{c}36 \\
(26.5)\end{array}$ & $\begin{array}{c}100 \\
(73.5)\end{array}$ & $\begin{array}{c}16 \\
(19.3)\end{array}$ & $\begin{array}{c}67 \\
(80.7)\end{array}$ & $\begin{array}{c}66 \\
(26.7)\end{array}$ & $\begin{array}{c}181 \\
(73.3)\end{array}$ \\
\hline & III & $\begin{array}{c}5 \\
(50.0)\end{array}$ & $\begin{array}{c}5 \\
(50.0)\end{array}$ & $\begin{array}{c}10 \\
(55.6)\end{array}$ & $\begin{array}{c}8 \\
(44.4)\end{array}$ & $\begin{array}{c}7 \\
(63.6)\end{array}$ & $\begin{array}{c}4 \\
(36.4)\end{array}$ & $\begin{array}{c}22 \\
(56.4)\end{array}$ & $\begin{array}{c}17 \\
(43.6)\end{array}$ \\
\hline \multicolumn{2}{|r|}{$\overline{\mathbf{a}}$} & $\begin{array}{c}50 \\
(64.1)\end{array}$ & $\begin{array}{c}28 \\
(35.9)\end{array}$ & $\begin{array}{c}170 \\
(49.1)\end{array}$ & $\begin{array}{c}176 \\
(50.9)\end{array}$ & $\begin{array}{c}260 \\
(45.1)\end{array}$ & $\begin{array}{c}316 \\
(54.9)\end{array}$ & $\begin{array}{c}480 \\
(48.0)\end{array}$ & $\begin{array}{c}520 \\
(52.0)\end{array}$ \\
\hline
\end{tabular}

表12 早期胃癌の予後（酎術例）（1950～1974）

\begin{tabular}{|c|c|c|c|}
\hline & 治瀷切除 & 非治渻切除 & 計 \\
\hline I & $50 / 52(96.2)$ & $1 / 4(25.0)$ & $51 / 56(91.1)$ \\
\hline II a & $68 / 70(97.1)$ & $2 / 3(66.7)$ & $70 / 73(95.9)$ \\
\hline II $\mathrm{a}+$ II $\mathrm{c}$ & $58 / 66(87.9)$ & $0 / 2(-)$ & $58 / 68(85.3)$ \\
\hline II b & $12 / 14(85.7)$ & - & $12 / 14(85.7)$ \\
\hline II $\mathrm{c}$ & $244 / 254(96.1)$ & $2 / 4(50.0)$ & $246 / 258(95.3)$ \\
\hline II $c+$ III & $189 / 201(94.0)$ & $8 / 10(80.0)$ & $197 / 211(93.4)$ \\
\hline III & $26 / 33(78.8)$ & - & $26 / 33(78.8)$ \\
\hline 計 & $647 / 690(93.8)$ & $13 / 23(56.5)$ & $660 / 713(92.6)$ \\
\hline
\end{tabular}

は, 分化型が87.8\% (223/254) と大半を占め, 未分化 型が12.2\%（31/254）であった. 陥四型早期癌におい ては，分化型が33.7\% (246/730)，末分化型が66.3\% （484/730）を占めた。 組織型の比率は，1970年以降の II c 型の増加に伴う陥凹型の増加でも，II c の分化/未分 化の比率は年次的に大差をみとめず同様の比率であった が，II c 型の增加は全体的飞みた時，50年代から70年代 に移りかわるにつれて分化型の相対的減少と未分化型の 相対的増加を推考することができる ${ }^{17) . ~}$

xii) 早期胃癌の予後 (表12)

早期胃癌の予後は良好であることは衆知の事実である が，1974年までの耐術切除例713例中の 5 年生存例は660 例で 5 年生存率は $92.6 \%$ でり, 治癒切除例で $93.8 \%$, 非治癒切除例に終った症例でもその予後は $56.5 \%$ あ゙あ た. 肉眼分類別にみてみると， III型がやや低いぐらいで
他は大差なく53例が 5 年以内に 死亡した。手術に対る す安全度は100\%であることが望 ましいのは当然である が，残念ながら早期胃癌1,000例中に 直接死亡例（術後 1 カ月以内死亡例）を 7 例経験し，その 因子は肺炎 4 例, 出血 1 例, 縫合不全 1 例, 自殺 1 例で, 70 歳以上の 高龄者に多かった，最近は中心静脈栄養等の普及，呼吸 循環器系に対する対策などにより術後管理の向上には, めざましいものがあり1975年以後直死例は経験しなくな った. 5 年以内死亡の内訳俚他病死 28 例, 不明 3 例, 癌 死22例で，之の再発形式は肝転移12例，局所再発 4 例， 播種性転移 3 例，肺転移 1 例，骨転移 2 例であった. 22 例中, 深達度 $\mathrm{m}$ は 2 例で，そのリンパ節転移は $\mathrm{n}_{2} \oplus$ であり骨転移と肝転移で失った。リンパ節転移 $\mathrm{n} \ominus$ げ, 再発したものは 3 例あり全例 $\operatorname{sm}$ で, 肝転移 2 例, 局所 再発 1 例であった.

\section{III むすび}

1950年に早期胃癌を経験して以来，1976年には手術例 は1,000例を越光，単発早期胃癌だけに 限れば1978年10 月に 1,000 例を越えた. 今回は単発早期胃癌 1,000 例につ いて肉眼分類を中心検討を加兄た．早期癌の時代的変 貌をみると，隆起型の占める割合は最近になるにつれて 次第に減少し, 逆に陷凹型早期癌, とくに I $\mathrm{c}$ 型の占め る割合が増壳 $50 \%$ 以上を占めるようになった点が特徽的 である、それは陥凹型の小さな胃癌が診断能力と技術の 向上で進行癌にならない前澄見でき，診断できるよう になった事が大きな因子であるらと推測する。

年齢分布は, 隆起型では60歳代をピークに山型の分布 
を示し，陥凹型では50歳代をピークに丘型の分布を示し た.このことは，隆起型に比へ，陥凹型にやや年踰の若 い層が多いことを示している，術前，癌の診断は今ゃ 100\%近くであり，早期胃癌の診断率は $82 \%$ 高くなっ ているが，深達度㟝断の上から進行癌としたものが16\% にみとめられ，いぜんとして深達度診断の困難性がみと められる. 早期胃癌診断の上で少数例に境界病変として 手術され組織検查で癌となったものがみとめられた。 た，良性疾患のまま手術がなされ，剔出標本全構築によ る詳細な組織検索の結果, 他の部位に微小胃癌が発見さ れたものもある. 粘膜内癌と粘膜下層癌とは，ほぼ半数 であったのは興味深い，隆起型と陥凹型の頻度の比較は 1 対 4 であった. 隆起型では sm 癌の方が多く, 陥凹 型では $\mathrm{m}$ 癌の方が多かった. 従来, 深達度 $\mathrm{m}$ の隆起 型早期癌では，リンパ節転移を認めない報告が多かった がわれわれはりンパ節転移を認めた 1 例を経験し，ま た深達度 $\mathrm{m}$ のI b 型早期癌にりンパ節転移を認めた 1 例をる経験した．われわれが集めえた報告では II b 型早 期癌のリンパ節転移例の報告はなかった ${ }^{18 / 19) 20321}$. 直死 例 7 例を除外した治瘾切除例の 5 年生存率は $93.8 \%$ と極 めて良好で早期癌の状態で治療をほどこせば，予後は十 分期待出来, 死因トップの污名と返上できると考兄る. それでる開腹時すでに肝転移や遠隔リンパ節への転移が あった症例もみられたことは，今後，胃症状を有しない 一般人への広範囲検診へと進まなければならず，外科的 処置に加えて科学の分野の発達から癌に対する対策を期 待することる必要ではないかと考学る。

本論文の要旨は第16回日本消化器外科学会において発 表した。

\section{文献}

1)人口動態統計（1 巻）1978年, 厚生省.

2) 田坂定孝 : 早期骨癌の全国集計 Gastroent. End. $4: 4-14,1961$.

3) 長与健夫 : 胃癌発生に関する組織学的実験的研 究. 日病会誌, $65: 3-25,1976$.

4) 高木国夫：微小胃癌の肉眼診断. 胃と腸, 5 : 939-949, 1970.

5) 高木国夫 : 早期胃癌. 臨床検查, $15: 630-640$, 1971.

6)高木国夫, 他：早期胃癌臨床診断の実態一内視 鏡的立場より一。胃と腸， $7: 331-338$, 1972.

7) 佐野量造：病理概評。胃と腸，6:68, 1972.

8) 二村雄次他：胃癌の症状について。癌の臨床, $22: 243-251,1976$.

9) 高木国夫 : 早期盟癌の肉眼診断と病理. 胃と腸, $2: 29-41,1967$

10)䗁田隆夫：早期胃癌発見の現状. Gastroent. Endo. 16：662-672, 1974.

11）北岡久三他：早期胃癌の手術成積。外科，36: $1468-1469,1974$.

12) 吉川謙蔵他：早期胃癌のリンパ節転移。癌の臨 床, $15: 699$-703, 1969 .

13) 胃癌取扱い規䄪：胃癌研究会編，金原出肘.

14）高木国夫, 大橋一郎, 太田博俊：早期胃癌手術 の問題点. 外科治療, 34:61-68, 1976.

15）梶谷 鐶，高木国夫：胃癌根治手術とその遠隔 成績。外科治療, $39: 679-685,1978$.

16) 中村恭一：胃癌の病理, 金芳堂.

17) 加藤 洋他：胃癌組織型の時代的推移. 胃々腸, $15: 19-25,1980$.

18）佐野量造：胃疾患の臨床病理，医学書院。

19）大井 至他：生檢により診断し得た微小 II b 型 早期胃癌の 1 例. 胃と腸, 5 : 469-475，1970,

20) 土井偉誉他：II b 型早期胃癌の 1 例. 胃と腸, 4 : 203-207, 1969.

21）原 義雄他：平坦型早期胃癌 II bの 1 例. 胃と 腸, $1: 569-571,1966$. 